\title{
Does IGF-1 play a role in the biology of endometrial cancer?
}

\author{
Dominika Majchrzak-Baczmańska, Andrzej Malinowski \\ Department of Surgical, Endoscopic and Oncologic Gynecology, Polish Mother's Memorial Hospital \\ - Research Institute, Lodz, Poland
}

\begin{abstract}
Insulin-like growth factor 1 (IGF-1) is a mitogen which plays a key role in regulating cell proliferation, differentiation, and apoptosis. It belongs to the family of proteins also composed of insulin-like growth factor 2 (IGF-2), two types of membrane receptors (IGF-1R and IGF-2R), 6 binding proteins (IGFBP 1-6), hydrolyzing proteases, and reactive molecules binding proteins, which regulate the activity of growth factors. Disturbances in the functioning of IGFBP/IGF/1GF1R can lead to induction of carcinogenesis, which has been demonstrated in breast, prostate or colon cancers. Findings evaluating the role of IGF-1 in endometrial cancer biology are ambiguous and contradictory. Therefore, in the present study, we analyzed the role of IGF-1 in the process of carcinogenesis of endometrial cancer, based on the available literature.
\end{abstract}

Key words: endometrial cancer, insulin-like growth factor-1, carcinogenesis

Ginekologia Polska 2016; 87, 8: 598-604

\section{INTRODUCTION}

Insulin-like growth factor-1 (IGF-1), also known as somatomedin 1 , is a mitogen which plays a pivotal role in regulating cell proliferation, differentiation, and apoptosis. IGF-1 is a member of a protein family which also includes insulin-like growth factor 2 (IGF-2), two types of membrane receptors (IGF-1R and IGF-2R), 6 binding proteins (IGFBP 1-6), hydrolyzing proteases, and other reactive molecules binding proteins which regulate the activity of growth factors [1]. Disturbances in the functioning of the IGFBP/IGF/1GF1R system may lead to the induction of carcinogenesis, which has been demonstrated in various types of malignancies, i.e. breast, prostate, or colon cancer. Both, increased activity of the IGF-1/IGF-1R complex and lowered IGF-BP expression have been mentioned among the promoting factors for neoplastic processes [2]. IGF-1 is believed to exert its mitogenic effect on various cells by stimulating their proliferation and inhibiting their apoptosis via endocrine, paracrine and autocrine mechanisms [1]. Results of various studies which evaluated the role of IGF-1 in the biology of endometrial cancer (EC) are ambiguous and conflicting.

\section{PHYSIOLOGICAL FUNCTION OF IGF-1}

IGF-1 is predominantly produced by hepatocytes as a response to growth hormone $(\mathrm{GH})$ activity and released to the serum of peripheral circulation blood. GH/IGF-1 cooperation is the main regulator of postnatal growth of the body, whereas IGF-2 plays a vital role during fetal development, and its synthesis is independent of $\mathrm{GH}$. Insulin-like growth factors may also be synthesized de novo in the cells of various tissues (ovary, endometrium, breast, lung), where - being mitogenic factors - they participate in cellular growth processes and elicit anabolic effects. The primary role of IGF-1 consists in promoting cell and tissue growth and division [3-5]. The literature offers a significant amount of evidence that molecules from the insulin-like growth factors participate in proliferation and differentiation of normal endometrial cells, as well as embryo implantation. Various studies have demonstrated the presence of IGF-1, IGF-1, and all 6 IGFBP proteins in the endometrium during a normal menstrual cycle [6]. IGF-1 circulates in blood either free or bound to low- or high-IGF affinity binding proteins. Six IGF-1 binding proteins (from IGFBP-1 to IGFBP-6) have been identified so far. Over $90 \%$ of the circulat- 
ing IGF-1 is bound to IGFBP-3 and ALS (acid-labile subunit), resulting in the formation of a $150 \mathrm{kDa}$ molecular mass complex. The remaining part forms complexes with other proteins and less than $1 \%$ is unbound, which constitutes the active form of IGF-1. The effect of IGF-1 on cells of various tissues is executed via its binding to a specific receptor. There are two types of receptors which demonstrate affinity to IGF-1, namely IGF-1R and IGF-2R. However, IGF-2R binds IGF-1 to a lesser degree as compared to IGF-1R, thus revealing higher affinity to IGF-2 [1].

\section{HYPOTHETICAL ROLE OF IGF-1 IN THE BIOLOGY OF ENDOMETRIAL CANCER}

Research on the role of IGF-1 in the biology of endometrial cancer was initiated on the basis of a hypothesis which had its roots in the correlation between endometrial cancer and the following conditions: obesity, type II diabetes, and the mitogenic effect of estrogens on the endometrium. Type 1, whose development depends on abnormal stimulation of the endometrium by endogenous as well as exogenous estrogens, accounts for a significant number of sporadic EC cases [7]. Studies have demonstrated that estrogens (mainly E2) stimulate cell proliferation by inducing autocrine IGF-1 synthesis and expression of IGF-1 receptor in the uterus [8]. Additionally, IGF-1 encoding gene has been detected to undergo expression mainly in the follicular phase and early luteal phase of a menstrual cycle $[9,7]$. Activation of the mitogenic effect of IGF-1 on the endometrium is the consequence of E2-dependent local production of IGF-1. Progesterone counteracts proliferation of endometrial cells, which is induced by estrogens via stimulation of the local synthesis of $17 \beta$-hydroxysteroid dehydrogenase and estrogen sulfotransferase. As a result of their expression, E2 is converted to a less active estrone (E1) and estrone sulfates, which are quickly expelled from the cells and the body. Additionally, as a result of progesterone activity, the synthesis of the IGF-1 binding protein (IGFBP-1), which blocks IGF-1 activity in the endometrium by controlling IGF-1 availability for its cellular receptors, is stimulated. Estrogen-induced production of IGF-1 molecule, in the absence of IGFBP-1 synthesis which depends on progesterone expression, results in abnormal proliferation of endometrial cells $[7,10]$. Recent reports in the literature have confirmed a correlation between EC and insulin resistance, hyperinsulinemia, and type II diabetes, which frequently constitute direct consequences of obesity. Insulin is believed to exert mitogenic effects on various cell types, especially cancerous cells, as a result of binding to a receptor or via other, non-receptor mechanisms, e.g. changing expression of IGF-1 and its binding proteins, or blocking of antiproliferative activity of progesterone. Insulin has been shown to stimulate mitogenic processes also by suppressing IGFBP-1 expression. Hyperinsulinemia may lead to lowered IGFBP-1 expression, even in the presence of progesterone, which probably results in a blockage of its protective activity [11].

\section{IGF-1 EXPRESSION IN TUMOR CELLS AND RESULTS OF IN VITRO STUDIES}

The results of in vitro studies demonstrate that IGF-1 participates in the process of EC carcinogenesis, both by induc-

\begin{tabular}{|c|c|c|c|c|c|}
\hline Parameter & Cell population & Experiment & Result of the experiment & $\begin{array}{l}\text { Role } \\
\text { in carcinogenesis? }\end{array}$ & Ref. \\
\hline IGF-1 & HEC-1B & IGF-1 incubation with HEC-1B & $\begin{array}{l}\text { KCC induction } \\
\text { KCC } 1 \text { expression }\end{array}$ & Yes & {$[12]$} \\
\hline $\begin{array}{l}\text { mRNA: } \\
\qquad \text { IGF-1 } \\
\text { IGF-1R }\end{array}$ & $\begin{array}{l}\text { RL95-2, KLE, } \\
\text { HEC, ISH }\end{array}$ & $\begin{array}{l}\text { Evaluation of IGF-1 synthesis in } \\
\text { the cells } \\
\text { Evaluation of mRNA expression: } \\
\text { IGF-1 } \\
\text { IGF-1R } \\
\text { aIR3 incubation with the cells }\end{array}$ & $\begin{array}{l}\text { Autocrine IGF-1 synthesis } \\
\text { Autocrine stimulation of the cells by IGF-1 } \\
\text { DNA synthesis induction in response to alR3 }\end{array}$ & Yes & [13] \\
\hline IGF-1 & HEC-1A, KLE & $\begin{array}{l}\text { IGF-1 incubation with HEC-1A } \\
\text { and KLE }\end{array}$ & Induced mitogenic activity of the cells & Yes & [14] \\
\hline $\begin{array}{l}\text { IGF-1 } \\
\text { E2 }\end{array}$ & ISH (ER+) & $\begin{array}{l}\text { E2 incubation with ISH (ER+) } \\
\text { Evaluation of IGF-1 activity after } \\
\text { cell incubation with E2 } \\
\text { IGF-1 incubation with ISH (ER+) }\end{array}$ & $\begin{array}{l}\text { Incubation with E2: } \rightarrow \text { induction of cell } \\
\text { proliferation } \rightarrow \text { induction IGF-1 secretion } \\
\text { Incubation with IGF-1 } \rightarrow \text { induction of cell } \\
\text { proliferation }\end{array}$ & Yes & [15] \\
\hline $\begin{array}{l}\text { IGF-1 } \\
\text { VEGF }\end{array}$ & HEC-1A (ER-) & IGF-1 incubation with HEC-1A & $\begin{array}{l}\text { Incubation with IGF-1 } \rightarrow \uparrow \text { mRNA VEGF } \\
\text { activity }\end{array}$ & Yes & [22] \\
\hline $\begin{array}{l}\text { IGF-1 } \\
\text { IGF-1R } \\
\text { IGFBPS }\end{array}$ & ISH, MCF-7 & Cell incubation with tamoxifen & $\begin{array}{l}\uparrow \text { ISH proliferation } \\
\text { Induction of IGF-1R phosphorylation }\end{array}$ & Yes & [26] \\
\hline
\end{tabular}


Table 2. IGF-1 - tumor tissue expression

\begin{tabular}{|c|c|c|c|c|}
\hline No. of samples & Parameter & Expression in EC tissues & Additional information & Ref. \\
\hline $26-$ total & IGF-1R & $\leftrightarrow$ & $\uparrow$ IGF-1R binding affinity in tumor tissues & [23] \\
\hline $\begin{array}{c}59-\mathrm{EC} \\
10-\mathrm{EH} \\
7-\mathrm{NE}\end{array}$ & $\begin{array}{l}\text { IGF-1R } \\
\text { IGF-1 } \\
\text { IGF-2R }\end{array}$ & $\begin{array}{l}\uparrow \\
\uparrow\end{array}$ & * & [20] \\
\hline $\begin{array}{c}152-\mathrm{VM} \\
(7-\mathrm{EC}) \\
63-\mathrm{NT}\end{array}$ & IGF-1R & $\uparrow$ & * & [24] \\
\hline $\begin{array}{l}30-\mathrm{EC} \\
30-\mathrm{NE}\end{array}$ & mRNA IGF-1 & $\uparrow$ & * & [16] \\
\hline $\begin{array}{l}15-\mathrm{EC} \\
45-\mathrm{NE}\end{array}$ & IGF-1 & $\leftrightarrow$ & * & [17] \\
\hline $\begin{array}{l}30-\mathrm{EC} \\
30-\mathrm{NE}\end{array}$ & $\begin{array}{c}\text { mRNA IGF-1 } \\
\text { IGF-1 (p) } \\
\text { IGF-1R (p) }\end{array}$ & $\begin{array}{l}\downarrow \\
\leftrightarrow \\
\leftrightarrow\end{array}$ & * & [21] \\
\hline $\begin{array}{l}11-\mathrm{EC} \\
42-\mathrm{NE}\end{array}$ & $\begin{array}{l}\text { mRNA IGF-1R } \\
\text { mRNA IGF-1 }\end{array}$ & $\begin{array}{c}\uparrow \\
\uparrow \text { type I EC } \\
\downarrow \text { type II EC }\end{array}$ & * & [18] \\
\hline $\begin{array}{l}13-\mathrm{EC} \\
10-\mathrm{NE}\end{array}$ & IGF-1 & $\uparrow E C$ cell proliferation & $\begin{array}{l}\text { Inc. of IGF-1 with cells from the } \\
\text { investigated samples was performed }\end{array}$ & [19] \\
\hline
\end{tabular}

$\leftrightarrow$ the same in cell tissues and normal healthy endometrial samples, $\uparrow$ increased, $\downarrow$ lowered, EC — endometrial cancer, EH — endometrial hyperplasia, inc. - incubation; NE - normal endometrium, VM — various malignancies, NT — normal tissues, (p) - protein product

ing proliferation of tumor cells and stimulating the process of neo-angiogenesis (Table 1) [12-15]. However, the results of in vivo studies are not as unambiguous (Table 2) [16-21].

Studies on the population of HEC-1B cells of EC revealed that induction of $\mathrm{KCl}$-cotransport (KCC) is the result of IGF-1 activity. Also, IGF-1 was found to lead to KCC 1 expression, which affects tumor invasion ability [12]. Reynolds et al., in their study of EC cells (RL95-2, KLE, HEC, ISH), detected the presence of autocrine IGF-1 synthesis and mRNA IGF-1 and IGF $1 \mathrm{R}$ expression in all cell populations. Inhibition of DNA synthesis in response to cell incubation with IGF-1 receptor-blocking antibody (aIR3) was observed in three cell lines (HEC 1A, KLE, ISH). These authors found autocrine stimulation of EC cells by IGF-1 in three out of four populations of the investigated cells [13]. Pear et al., noted induction of time-dependent mitogenic activity of EC cells as a result of incubation of the cell populations (HEC $1 \mathrm{~A}$ and KLE) with exogenous IGF-1. IGF-1 was found to play a regulatory role in the processes of EC cell growth. The authors postulated IGF-1 to mediate in estrogen-dependent proliferation of EC cells [14]. Kashima et al., in their study on EC cell population (ISH) expressing ER, concluded that dose-dependent E2-induced proliferation of the cancerous cells occurs via the MAPK3/1 signaling pathway as a result of autocrine stimulation of IGF-1. They also analyzed EC tissues and normal endometrial samples and reported MAPK3/1 expression and phosphorylation both, in tumor samples and healthy endometrium, although MAPK3/1 expression was statistically significantly higher in EC cells [15]. Bermont et al., conducted an experimental study on estrogen receptor-negative EC cells in order to assess IGF-1 role in the process of tumor neoangiogenesis. They found a dose- and time-dependent increase in VEGF mRNA expression, and an increased concentration of its protein product after 24 and 48 hour-incubation of the HEC-1A cell line with exogenous IGF-1. These authors suggested that estrogen-dependent activation of the IGF-1 autocrine loop may result in tumor growth by stimulating the process of neoangiogenesis [22]. The presence of IGF-1R receptors were demonstrated both, in EC tissues and healthy endometrium (Table 2) [20, 23, 24]. Regardless, statistically significantly higher receptor binding affinity was found in EC tissues as compared to healthy endometrium. Also, IGF-1R binding affinity was proven to increase in response to decreasing tumor differentiation [23, 25]. Additionally, tamoxifen, which is used in breast cancer therapy and which is a risk factor for the development of EC, has been demonstrated to lead to EC cell proliferation by inducing IGF-1R phosphorylation [26]. Furthermore, a dysregulation of genes encoding the components of the IGF-1 autocrine system and the ER receptor in the endometrium was also detected, which in consequence might lead to the development of EC [27].

On the other hand, Soufla et al., in a study of 30 postoperative EC preparations and 30 normal endometrial samples from the same patients, found no statistically significant differences in the mRNA IGF-1 transcription levels in both groups. On further analysis, these authors detected both, overexpression and lowered mRNA IGF-1 expression (39\% 
and $56 \%$ of the cases) in tumor tissues as compared to the transcript level of that factor in normal healthy endometrium. Regardless, they emphasize that the presence of mRNA IGF-1 overexpression constitutes an important element in the oncogenesis of EC because it is associated with the process of tumor neoangiogenesis [16]. Toole et al., observed lowered IGF-1, ERa, ERb, and PR (progesterone receptor) expression in EC tissues as compared to healthy endometrial samples [17]. Maiorano et al., in a study of postoperative EC preparations and healthy endometrial samples, found a lowered mRNA IGF-1 expression in tumor cells as compared to healthy tissues. In turn, the level of IGF-1 and IGF-1R protein products, measured by immunohistochemistry, was the same in tumor cells and healthy endometrium. These authors postulate that perhaps the IGF-1 system is not directly involved in the carcinogenesis of EC [21]. Roy et al., reported mRNA IGF-1R overexpression in all of the investigated EC tissues, whereas increased mRNA IGF-1 was detected only in cancers developing on the basis of an endometrial hyperplasia with atypia - type $1 \mathrm{EC}$. Lowered mRNA IGF-1 expression was observed in type 2 EC. Thus, these authors postulated the existence of two different mechanisms which activate IGF-1R in endometrial cancer: ligand-dependent in type $1 \mathrm{EC}$ and ligand-independent in type 2 EC [18]. Reynolds et al., in their study of 13 EC preparations and 10 healthy endometrium samples, found that incubation of tumor tissues with IGF-1 results in higher EC cell proliferation. Interestingly, these authors observed that tissue proliferation of healthy endometrium is inhibited by IGF-1, EGF and TGF-alfa, and stimulated by cell incubation with Ab528 and a IR3 antibodies. The situation was reversed in case of EC cells. Based on their findings, these authors claimed the existence of a different, growth factor-dependent mechanism of tumor cell and heathy endometrium proliferation [19]. Pavelić et al., observed an increased IGF-1, IGF-1R, and IGF-2R expression in EC tissues, especially in FIGO stage III and IV, as compared to healthy endometrium, and endometrial hyperplasia with atypia. They found that specific inhibition of IGF-1R, and IGF-2R activity resulted in inhibition of tumor cell proliferation. They implied that the local IGF-1 autocrine loop may play an important role in tumor progression [20].

\section{SERUM IGF-1 AND ENDOMETRIAL CANCER}

Researchers, inspired by the results of EC cell and tissue tests, started to investigate serum IGF-1 in women with endometrial cancer. However, these studies are scarce and the results remain inconsistent (Table 3) [10, 28-35].

\begin{tabular}{|c|c|c|c|c|}
\hline No. of patients & IGF-1 concentration & Additional information & Study oversight & Ref. \\
\hline $\begin{array}{c}166-\mathrm{EC} \\
315-\text { controls }\end{array}$ & $\leftrightarrow$ & $\begin{array}{l}\text { Detailed } \\
\text { Prospective study }\end{array}$ & * & {$[10]$} \\
\hline $\begin{array}{c}288-\mathrm{EC} \\
392-\text { controls }\end{array}$ & $\leftrightarrow$ & Detailed analysis & * & [29] \\
\hline $\begin{array}{c}73-\mathrm{EC} \\
108-\text { controls }\end{array}$ & $\leftrightarrow$ & Detailed analysis & * & {$[28]$} \\
\hline $\begin{array}{c}174-\mathrm{EC} \\
136-\text { controls }\end{array}$ & $\leftrightarrow$ & Detailed analysis & * & [30] \\
\hline $\begin{array}{c}692-\mathrm{EC} \\
1723-\text { controls }\end{array}$ & * & $\begin{array}{l}\text { No link between IGF-1 gene } \\
\text { polymorphism and risk for EC }\end{array}$ & * & [36] \\
\hline $\begin{array}{c}32-\mathrm{EC} \\
18-\text { controls }\end{array}$ & $\downarrow$ & $\begin{array}{l}\text { Impaired glucose tolerance and } \\
\text { hyperinsulinemia in EC women might } \\
\text { have affected the results }\end{array}$ & CVD not included & {$[32]$} \\
\hline $\begin{array}{c}250-\mathrm{EC} \\
465-\text { controls }\end{array}$ & $\downarrow$ & $\begin{array}{c}\uparrow \text { insulin levels in EC women might have } \\
\text { affected the results }\end{array}$ & CVD not included & {$[51]$} \\
\hline $\begin{array}{c}84-\mathrm{EC} \\
84-\text { controls }\end{array}$ & $\downarrow$ & * & CVD not included & [33] \\
\hline $\begin{array}{c}56-\mathrm{EC} \\
40-\text { controls }\end{array}$ & $\downarrow$ & * & $\begin{array}{l}\text { CVD, impaired glucose } \\
\text { tolerance, diabetes not included }\end{array}$ & [31] \\
\hline $\begin{array}{c}24-\text { EC } \\
12-\text { EH with atypia } \\
31-\text { EH without atypia } \\
52-\text { controls (2 groups) }\end{array}$ & $\uparrow$ & * & CVD, HRT, HC not included & [35] \\
\hline $\begin{array}{c}18-\mathrm{EC} \\
8-\text { controls }\end{array}$ & $\uparrow$ & * & CVD not included & {$[48]$} \\
\hline
\end{tabular}

$\leftrightarrow$ the same in cell tissues and normal healthy endometrial samples, $\uparrow$ increased, $\downarrow$ lowered, EC — endometrial cancer, EH — endometrial hyperplasia, CVD - cardiovascular diseases, HC — hormonal contraception, HRT — hormone replacement therapy 
Four studies found no association between serum IGF-1 and EC biology [10, 28-30]. Lukanova et al., in a multi-center prospective study in 481 women (166 — study group, 315 - controls), reported no link between the risk for EC and serum IGF-1 levels. They found no statistically significant differences between serum IGF-1 concentration and EC as compared to healthy women, regardless of their menopausal status at the time of blood collection (most women were postmenopausal at the time of testing) [10]. Three other authors, in detailed analyses of large groups of patients, also found no statistically significant differences between serum IGF-1 concentration of women with EC as compared to healthy controls, or an association between that parameter and the risk for EC [28-30]. McGrath et al., in a large multi-center study including 2014 subjects (692 - women with EC, 1723 - controls) found no statistically significant correlation between IGF-1 gene polymorphism and the risk for EC. These authors imply that genetic variability in IGF-1 has no effect on the occurrence of EC [36].

Importantly, serum IGF-1 is synthesized mainly in the liver, and its level is affected by numerous endogenous - genetic predispositions, and exogenous factors - diet, physical exercise, medication use, including HRT, BMI, chronic disease (DM, cardiovascular and other conditions), as well as age [37-47]. Authors of the abovementioned publications adjusted their results to the factors which might potentially affect the results of their analyses. Also, the studies took into account the menopausal status of the study participants as the analysis of serum IGF-1 levels in women with breast and ovarian cancers demonstrated a correlation between elevated serum IGF-1 levels and the risk for developing these cancers only in young patients, i.e. $<55$ years of age, while no such association was found for postmenopausal women [48-50].

Some studies detected statistically significantly lower or higher serum IGF-1 levels in women with EC as compared to healthy controls $[31-35,51]$.

Four teams found statistically significantly lower IGF-1 levels in subjects with EC as compared to healthy women [31-35,51], but they did not account for the possibility of cardiovascular diseases in the investigated populations (common in older, postmenopausal patients), what might be a serious study limitation due to a proven link between lowered serum IGF-1 level and these pathologies [40, 42].

Additionally, Rutanen et al., in their study on total serum IGF-1 level, found a statistically significantly higher incidence of impaired glucose tolerance and hyperinsulinemia in women with EC as compared to controls, which - even according to these authors - might have affected the findings of the study [32]. Gunter et al., also reported elevated serum insulin levels in patients at higher risk for developing EC cancer, which also might have influenced the final results of their analysis [51]. Studies indicate lowered serum total IGF-1 levels in women with hyperinsulinemia and impaired glucose tolerance $[43,44]$. Serum free IGF-1 levels in women with type II diabetes are statistically significantly higher as compared to healthy populations [44].

The study by Baloglu et al., generated particularly interesting results as these authors not only did not observe lower serum total IGF-1 levels in women with EC as compared to controls, but also noted decreased concentrations of that factor as the disease progressed [serum free IGF-1 levels were lower in women with myometrial infiltration (24 cases) as compared to infiltration-free women (32 cases)]. The results were surprising even for the authors, who stated they might have reflected disturbances in the functioning of the autocrine IGF-1 system in the uterus [31]. However, Lukanova is of the opinion that the locally produced IGF-1, whose synthesis is dominated by estrogens, participates in tumor biology, and serum IGF-1 level produced mainly in the liver as a response to $\mathrm{GH}$ activity is not a good marker of autocrine IGF-1 synthesis in the endometrium [10]. Besides, numerous factors affect the levels of serum IGF-1, including cardiovascular diseases, impaired glucose tolerance, elevated insulin levels, which often precede symptomatic diabetes type II, and that was not taken into consideration by these authors. Therefore, it remains unclear whether the obtained results indeed reflect the lowering IGF-1 level as the disease progresses, or whether they are caused by other reasons. The main limitation of the study by Baloglu et al., was the fact that they did not include patients with advanced-stage EC in their analysis, so the question whether the tendency for the serum IGF-1 level to drop would also be confirmed in more advanced disease, or disappear altogether, remains unanswered. Moreover, bearing in mind that most studies have confirmed the role of local IGF-1 loop in the biology of $E C$, the inverse correlation between serum IGF-1 level and disease advancement is unlikely to result from the process of endometrial carcinogenesis.

Two teams observed elevated serum IGF-1 levels in EC women as compared to controls [34,35]. Waksmański et al., noted statistically significantly higher serum IGF-1 levels in women with EC and hyperplasia with atypia as compared to patients with normal endometrium. However, these authors failed to consider the possibility of HRT or hormonal contraceptive use, or the existence of cardiovascular diseases, which might have significantly affected the obtained results. That oversight questions the reliability of their findings [35]. Various authors have demonstrated that oral HRT leads to statistically significant decrease in serum IGF-1 levels, probably as a result of direct inhibition of its synthesis in the liver by the orally ingested estrogen [47]. Similarly to Waksmański et al., Ayabe et al., reported statistically significantly higher serum IGF-1 levels in post- 
menopausal Japanese women with EC (18 cases) as compared to controls (8 cases). They did not observe statistically significant differences in IGF-1 levels among premenopausal women with EC ac compared to controls (5 - study group, 19 - controls). However, they did not take into account the possibility of coexisting cardiovascular diseases, and the sample size was particularly small. Therefore, their study may not constitute a reliable proof for undisputed role of serum IGF-1 in the biology of EC. Furthermore, as was suggested by the authors themselves, higher serum IGF-1 levels in postmenopausal Japanese women with EC might have been the result of varying parameter values between different races [48]. Several studies have reported that serum IGF-1 levels may be determined by ethnicity [52]. The majority of the abovementioned studies investigated Caucasian women, and only the study by Gunter et al., included 24 Asian subjects (7 - study group, 17 - controls) out of 715 all participants, although these authors did not mention any differences in IGF-1 concentration depending on the race [51]. Moreover, there is no consensus among researchers as to whether differences in serum IGF- levels are dependent on ethnicity [52].

\section{CONCLUSIONS}

On the basis of the abovementioned analysis of the literature, it seems safe to conclude that serum IGF-1 most probably does not participate in the process of endometrial carcinogenesis. The IGF-1 autocrine loop, which is present in the uterus, is believed to play a more significant role. Endometrial cancer affects mainly older, postmenopausal women, which might be an analogy to ovarian and breast cancers where, in case of postmenopausal patients, local IGF-1 system, rather than the factor present in the serum of the peripheral circulation, plays a role in tumor biology. Hypothetically, one cannot exclude the possibility that some women with EC present elevated serum IGF-1 levels, de facto resulting from the disease, as compared to normal healthy women, in which case that factor may participate, together with locally produced IGF-1, in the process of tumor oncogenesis. The presence of low serum IGF-1 concentration in EC women as compared to controls, which is supposed to result from the neoplastic process and show a dysregulation of IGF-1 system functioning in the uterus, seems to be rather unlikely, especially taking into account tumor biology, as well as the results of various studies which demonstrate the mitogenic effect of that factor on EC cells. On the other hand, some in vivo studies of EC tissue preparations dismissed the possibility that insulin-like growth factor 1 plays a significant role in tumor biology. Thus, it is possible that neither serum IGF-1 nor local autocrine system, which is involved in the physiological processes of normal healthy endometrium, participate in the oncogenesis of endometrial cancer.

\section{REFERENCES}

1. $\mathrm{Yu} \mathrm{H}$, Rohan T. Role of the insulin-like growth factor family in cancer development and progression. J Nat/ Cancer Inst. 2000, 92 (18), 1472-1489.

2. Druckmann R, Rohr UD. IGF-I in gynaecology and obstetrics. Maturitas. 2002, 41, 65-83.

3. Cohen P, Clemmons DR, Rosenfeld R. Does the GHIGF axis play a role in cancer pathogenesis? Growth Horm. IGF Res. 2000, 10, 297-305.

4. Grimberg A, Cohen P. Role of insulin-like growth factors and their binding proteins in growth control and carcinogenesis. J. Cell Physiol. 2000, 183 (1), 1-9.

5. Wu X, Tortolero-Luna G, Zhao H, [et al.]. Serum levels of insulin-like growth factor I and risk of squamous intraepithelial lesions of the cervix. Clin. Cancer Res. 2003, 9, 3356-3361.

6. Wang HS, Chard T. IGFs and IGF-binding proteins in the regulation of human ovarian and endometrial function. J Endocrinol. 1999, 161, 1-13.

7. Kaaks R, Lukanova A, Kurzer MS. Obesity, endogenous hormones, and endometrial cancer risk: a synthetic review. Cancer Epidemiol Biomarkers Prev. 2002, 11, 1531-1543.

8. Huynh HT, Pollak M. Insulin-like growth factor I gene expression in the uterus is stimulated by tamoxifen and inhibited by the pure antiestrogen. Cancer Res. 1993, 53 (23), 5585-5588.

9. Tang XM, Rossi MJ, Masterson BJ, [et al.]. Insulin-like growth factor I (IGF-I), IGF-I receptors, and IGF binding proteins 1-4 in human uterine tissue: tissue localization and IGF-I action in endometrial stromal and myometrial smooth muscle cells in vitro. Biol Reprod. 1994, 50 (5), 1113-1125.

10. Lukanova A, Zeleniuch-Jacquotte $A$, Lundin $E$, [et al.]. Prediagnostic levels of C-peptide, IGF-I, IGFBP -1, -2 and -3 and risk of endometrial cancer. Int J Cancer. 2004, 108 (2), 262-268.

11. Session DR, Kalli KR, Tummon IS, [et al.]. Treatment of atypical endometrial hyperplasia with an insulin-sensitizing agent. Gynecol Endocrinol. 2003, 17, 405-407.

12. Shang C, Lu YM, Meng LR. KCC1 gene advances cell invasion ability by regulating ERK signaling pathway in endometrial cancer HEC-1B cell line. Int J Gynecol Cancer. 2011, 21 (5), 795-799.

13. Reynolds RK, Hu C, Baker VV. Transforming growth factor-alpha and insulin-like growth factor-I, but not epidermal growth factor, elicit autocrine stimulation of mitogenesis in endometrial cancer cell lines. Gynecol Oncol. 1998, 70 (2), 202-209.

14. Pearl ML, Talavera F, Gretz HF, [et al.]. Mitogenic activity of growth factors in the human endometrial adenocarcinoma cell lines HEC-1-A and KLE. Gynecol Oncol. 1993, 49 (3), 325-332.

15. Kashima H, Shiozawa T, Miyamoto $\mathrm{T}$, [et al.]. Autocrine stimulation of IGF1 in estrogen-induced growth of endometrial carcinoma cells: involvement of the mitogen-activated protein kinase pathway followed by up-regulation of cyclin D1 and cyclin E. Endocr Relat Cancer. 2009, $16(1), 113-122$

16. Soufla G, Sifakis S, Spandidos DA. FGF2 transcript levels are positively correlated with EGF and IGF-1 in the malignant endometrium. Cancer Lett. 2008, 259 (2), 146-155.

17. O'Toole SA, Dunn E, Sheppard BL, [et al.]. Oestrogen regulated gene expression in normal and malignant endometrial tissue. Maturitas. 2005, 51 (2), 187-198.

18. Roy RN, Gerulath AH, Cecutti A, [et al.]. Discordant expression of insulin-like growth factors and their receptor messenger ribonucleic acids in endometrial carcinomas relative to normal endometrium. Mol Cell Endocrinol. 1999, 153 (1-2), 19-27.

19. Reynolds RK, Owens CA, Roberts JA. Cultured endometrial cancer cells exhibit autocrine growth factor stimulation that is not observed in cultured normal endometrial cells. Gynecol Oncol. 1996, 60 (3), 380-386.

20. Pavelić J, Radaković B, Pavelić K. Insulin-like growth factor 2 and its receptors (IGF $1 \mathrm{R}$ and IGF $2 \mathrm{R} /$ mannose 6 -phosphate) in endometrial adenocarcinoma. Gynecol Oncol. 2007, 105 (3), 727-735.

21. Maiorano $E$, Loverro $G$, Viale $G$, [et al.]. Insulin-like growth factor-I expression in normal and diseased endometrium. Int J Cancer. 1999, 80 (2), 188-193.

22. Bermont $\mathrm{L}$, Lamielle F, Fauconnet $\mathrm{S}$, [et al.]. Regulation of vascular endothelial growth factor expression by insulin-like growth factor-l in endometrial adenocarcinoma cells. Int J Cancer. 2000, 85 (1), 117-123.

23. Talavera F, Reynolds RK, Roberts JA, [et al.]. Insulin-like growth factor I receptors in normal and neoplastic human endometrium. Cancer Res. 1990, 50 (10), 3019-3024.

24. Ouban A, Muraca P, Yeatman T, [et al.]. Expression and distribution of insulin-like growth factor-1 receptor in human carcinomas. Human Pathology. 2003, 34 (8), 803-808. 
25. Nagamani M, Stuart CA, Dunhardt PA, [et al.]. Specific binding sites for insulin and insulin-like growth factor I in human endometrial cancer. Am J Obstet Gynecol. 1991, 165 (6), 1865-1871.

26. Karas M, Kleinman D, Danilenko M, [et al.]. Components of the IGF system mediate the opposing effects of tamoxifen on endometrial and breast cancer cell growth. Prog Growth Factor Res. 1995, 6 (2-4), 513-520.

27. Strissel PL, Ellmann S, Loprich E, [et al.]. Early aberrant insulin-like growth factor signaling in the progression to endometrial carcinoma is augmented by tamoxifen. Int J Cancer. 2008, 123 (12), 2871-2879.

28. Augustin LS, Dal Maso L, Franceschi S, [et al.]. Association between components of the insulin-like growth factor system and endometrial cancer risk. Oncology. 2004, 67 (1), 54-59.

29. Weiderpass E, Brismar K, Bellocco R, [et al.]. Serum levels of insulin-like growth factor-I, IGF-binding protein 1 and 3 , and insulin and endometrial cancer risk. Br J Cancer. 2003, 89 (9), 1697-1704.

30. Lacey JV Jr, Potischman N, Madigan MP, [et al.]. Insulin-like growth factors, insulin-like growth factor-binding proteins, and endometrial cancer in postmenopausal women: results from a U.S. case-control study. Cancer Epidemiol Biomarkers Prev. 2004, 13 (4), 607-612.

31. Baloglu A, Bezircioglu I, Cetinkaya B, [et al.]. Prospective clinical study of the association between plasma level of free IGF-1 and myometrial invasion min patients with endometrial adenocarcinoma. Ginekol Pol. 2010, 81 (7), 501-505.

32. Rutanen EM, Stenman S, Blum W, [et al.]. Relationship between carbohydrate metabolism and serum insulin-like growth factor system in postmenopausal women: comparison of endometrial cancer patients with healthy controls. J Clin Endocrinol Metab. 1993, 77 (1), 199-204.

33. Petridou $E$, Koukoulomatis $\mathrm{P}$, Alexe DM, [et al.]. Endometrial cancer and the IGF system: a case-control study in Greece. Oncology. 2003, 64 (4), 341-345.

34. Ayabe $\mathrm{T}$, Tsutsumi $\mathrm{O}$, Sakai $\mathrm{H}$, [et al.]. Increased circulating levels of insulin-like growth factor-I and decreased circulating levels of insulin-like growth factor binding protein-1 in postmenopausal women with endometrial cancer. Endocr J. 1997, 44 (3), 419-424.

35. Waksmański B, Dudkiewicz J, Dabrowski S. Function of insulin-like growth factor (IGF-I) and its binding protein (IGFBP-1) in pathological proliferation of endometrium. Wiad Lek. 2001, 55 (11-12), 656-661.

36. McGrath M, Lee IM, Buring J, [et al.]. Common genetic variation within IGFI, IGFII, IGFBP-1, and IGFBP-3 and endometrial cancer risk. Gynecol Oncol. 2011, 120 (2), 174-178.

37. Juul A. Serum levels of insulin-like growth factor I and its binding proteins in health and disease. Growth Horm IGF Res. 2003, 13, 113-170.

38. Hankinson SE, Willett WC, Colditz GA, [et al.]. Circulating concentrations of insulin-like growth factor-I and risk of breast cancer. Lancet. 1998, 351, 1393-1396.
39. Leone A, Di Gennaro E, Bruzzese F, [et al.]. New perspective for an old antidiabetic drug: metformin as anticancer agent. Cancer Treat Res. 2014, 159, 355-376.

40. Zhang L, Curhan GC, Forman JP. Plasma insulin-like growth factor-1 level and risk of incident hypertension in nondiabetic women. $J$ Hypertens. 2011, 29 (2), 229-235.

41. Xie L, Wang W. Weight control and cancer preventive mechanisms: role of insulin growth factor-1-mediated signaling pathways. Exp Biol Med. 2013, 238 (2), 127-132.

42. van Bunderen CC, Oosterwerff MM, van Schoor NM, [et al.]. Serum IGF1, metabolic syndrome, and incident cardiovascular disease in older people: a population-based study. Eur J Endocrinol. 2013, 168 (3), 393-401.

43. Sesti G, Sciacqua A, Cardellini M, [et al.]. Plasma concentration of IGF-I is independently associated with insulin sensitivity in subjects with different degrees of glucose tolerance. Diabetes Care. 2005, 28 (1), 120-125.

44. Rajpathak SN, Gunter MJ, Wylie-Rosett J, [et al.]. The role of insulin-like growth factor-I and its binding proteins in glucose homeostasis and type 2 diabetes. Diabetes Metab Res Rev. 2009, 25 (1), 3-12.

45. Decensi A'Bonanni B, Baglietto L, [et al.]. A two-by-two factorial trial comparing oral with transdermal estrogen therapy and fenretinide with placebo on breast cancer biomarkers. Clin Cancer Res. 2004, 10 (13), 4389-4397.

46. Harrela $\mathrm{M}$, Koistinen $\mathrm{H}$, Kaprio J, [et al.]. Genetic and environmental components of interindividual variation in circulating levels of IGF-I, IGF-II, IGFBP-1, and IGFBP-3. J Clin Invest. 1996, 98 (11), 2612-2615.

47. Trobec K, von Haehling S, Anker SD, [et al.]. Growth hormone, insulin-like growth factor 1, and insulin signaling - a pharmacological target in body wasting and cachexia. J Cachexia Sarcopenia Muscle. 2011, 2 (4), 191-200.

48. Lukanova A, Lundin E, Toniolo P, [et al.]. Circulating levels of insulin-like growth factor-l and risk of ovarian cancer. Int JCancer. 2002, 101 (6), 549-554.

49. Peeters PH, Lukanova A, Allen N, [et al.]. Serum IGF-I, its major binding protein (IGFBP-3) and epithelial ovarian cancer risk: the European Prospective Investigation into Cancer and Nutrition (EPIC). Endocr Relat Cancer. 2007, 14 (1), 81-90.

50. O, Gibson L, Johnson N, [et al.]. Polymorphisms and circulating levels in the insulin-like growth factor system and risk of breast cancer: a systematic review. Cancer Epidemiol Biomarkers Prev. 2005, 14 (1), 2-19.

51. Gunter MJ, Hoover DR, Yu H, [et al.]. A prospective evaluation of insulin and insulin-like growth factor-I as risk factors for endometrial cancer. Cancer Epidemiol Biomarkers Prev. 2008, 17 (4), 921-929.

52. Juul A, Scheike T, Pedersen AT, [et al.]. Changes in serum concentrations of growth hormone, insulin, insulin-like growth factor and insulin-like growth factor-binding proteins 1 and 3 and urinary growth hormone excretion during the menstrual cycle. Hum Reprod. 1997, 12 (10), 2123-2128. 